\title{
INFLUENCE OF STEAM EXPLOSION ON MATERIAL PROPERTIES UNDER PRESSURE AGGLOMERATION
}

\begin{abstract}
Adam ŚWIĘTOCHOWSKI, PhD. Department of Agricultural and Forest Engineering, Faculty of Production Engineering, Warsaw University of Life Sciences, Nowoursynowska Street 166, 02-787 Warsaw, Poland, e-mail: adam_swietochowski@sggw.pl (Coresponding author)

Jakub GAWRON, PhD. Department of Production Management and Engineering, Faculty of Production Engineering, Warsaw University of Life Sciences, Poland, Faculty of Production Engineering, Warsaw University of Life Sciences, Nowoursynowska Street 166, 02-787 Warsaw, Poland, e-mail: jakub_gawron@sggw.pl

Magdalena DĄBROWSKA, PhD. Department of Agricultural and Forest Engineering, Faculty of Production Engineering, Warsaw University of Life Sciences, Nowoursynowska Street 166, 02-787 Warsaw, Poland, e-mail: magdalena_dabrowska@sggw.pl Aleksander LISOWSKI, Prof. PhD. Department of Agricultural and Forest Engineering, Faculty of Production Engineering, Warsaw University of Life Sciences, Nowoursynowska Street 166, 02-787 Warsaw, Poland, e-mail: aleksander_lisowski@sggw.pl

The purpose of the study was to determine the influence of the steam explosion process on the change in properties of the material subjected to this process. Wood chips were used before and after the steam explosion (SE), and pellets made from wood chips subjected to steam explosions (black pellet). The scope of the study included determination of physical and chemical characteristics such as moisture content, combustion heat and calorific value, determination of lignin and hemicellulose, cellulose and hydrogen, carbon, nitrogen and sulfur content. hemicellulose compounds. After the process biomass, there are still mainly cellulose and lignin compounds that are readily biodegradable. The process results in a slight increase in material humidity and lower calorific value, but further processing in the form of agglomeration results in reversal of these effects.
\end{abstract}

Keywords: black pellet, steam explosion, wood chips

\section{INTRODUCTION}

Pellets with improved properties such as water resistance and lower dust content which can reduce the high cost of storage and transport are currently available on the market. These pellets stored under high humidity conditions at both ambient and elevated temperatures are characterized by a higher mechanical strength compared to other types of pellets (Graham et al., 2016). Unfortunately, with the increase in the quality of the granulates the cost of their production increases. Black pellets compared to standard pellets provide significant savings due to the lower storage and transport costs (Björklund, 2016). Another advantage of improved pellets is the fact that they do not present a danger of self-ignition (Graham et al., 2016). To improve the properties of pellets, the raw material is subjected to additional heat treatment. The most common is torrefaction, and pellets obtained from the raw material after this treatment have advantages such as: shorter ignition time, lower moisture content and better grindability (Jakubiak and Kordylewski, 2009).

Another solution is a steam explosion. In this process biomass is treated with steam at a temperature of 180 $240^{\circ} \mathrm{C}$ under pressure of 1-3,5 MPa. During heating, the intermolecular bonds break off and reduce the molecular weight of lignin. Then the hot and softened biomass is expanded. A sudden decrease in pressure to atmospheric pressure leads to a partial destruction of the biomass structure (Grala et al., 2014). The main source of fiberisation are shear forces created during passing the biomass through the expansion valve to the cyclone. Hot lignin and released sugars link together and create a pseudo-lignin structure that improves the binding properties of the material. In the pressure agglomeration process a valuable product is obtained. Pellets made of material treated with steam explosion have dark colour and smooth, glassy surface. These pellets are characterized by increased calorific value, relatively high bulk density and moreover, have hydrophobic properties (Adapa et al., 2010; Björklund, 2016; Stelte, 2013). The conventional mechanical methods were reported to require roughly $70 \%$ more energy to achieve the same size reduction as explosive depressurization (Holtzapple et al., 1989). The particle sizes and initial bulk density of biomass have been identified as important factors in conversion woody biomass into pellets. In general, smaller particle sizes led to higher bulk densities with closer packing (Lam et al., 2008; Mani et al., 2006). The purpose of the study was to

Copyright (C) 2017 The Authors. Published by Aleksandras Stulginskis University. This is an open-access article distributed under the terms of the Creative Commons Attribution License (CC-BY 4.0), which permits unrestricted use, distribution, and reproduction in any medium, provided the original author and source are credited. 
determine the influence of the steam explosion process on the changes in properties of the material subjected to this process.

\section{MATERIALS AND METHODS}

Research were carried out in the Department of Agricultural and Forest Engineering, Faculty of Production Engineering at Warsaw University of Life Sciences. Wood chips of coniferous wood originated from Canadian forests, before and after steam explosion (SE), and pellets made of wood chips subjected to steam explosion (black pellets) were used.
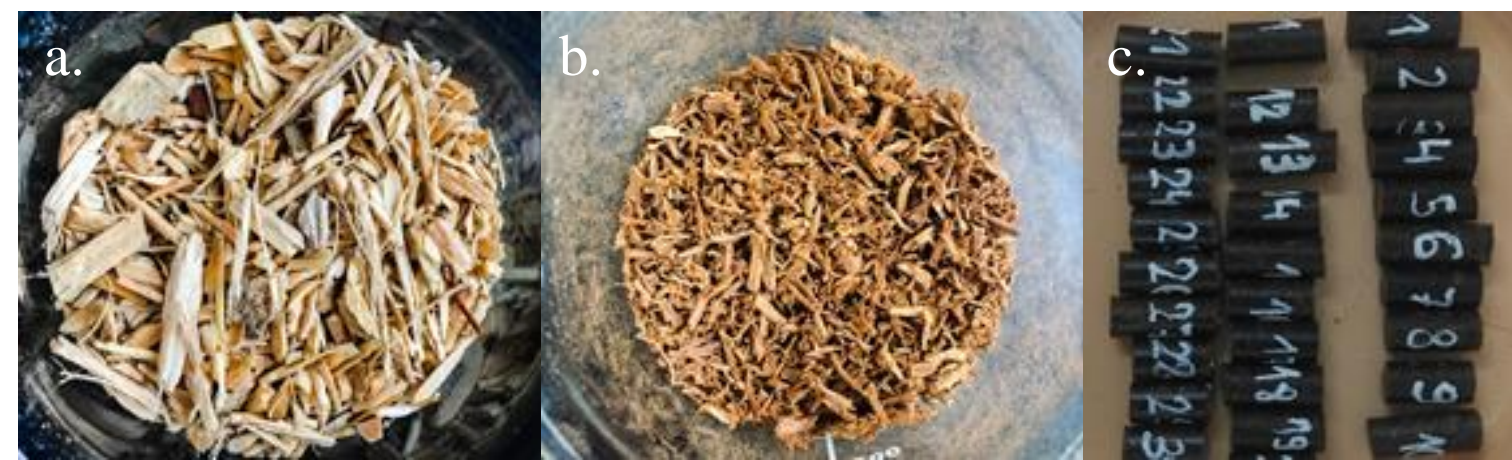

Figure 1. Material used for testing: a - raw material, b - material after steam explosion, $\mathrm{c}$ - black pellets

The scope of the study included determination of physical and chemical characteristics such as moisture content, gross and net calorific values, lignin, hemicellulose, cellulose contents and hydrogen, carbon, nitrogen and sulfur contents.

Determination of moisture content was carried out using the drying-weighing method according to the PN-EN 15414 3:2011 standard. Samples were dried in the laboratory drier (SLW $115 \mathrm{TOP}+$ ) in the temperature of $105^{\circ} \mathrm{C}$ for complete drying. Moisture content was calculated as a ratio of a mass of water contained in the material to the total weight of the moist material. Arithmetic mean of moisture content for 3 determinations was considered as representative.

Tests of cellulose, hemicellulose and lignin contents were carried out using the UV/VIS Shimadzu spectrometer, model UVmini 1240. The extraction was carried out with a mixture of chloroform and 96\% ethyl alcohol in a ratio of 93:7 in (Antczak et al., 2006). Percentage of extractable substances was calculated according to the formula (Krutul, 2002):

$$
E=\frac{100 \cdot a}{n}
$$

where:

$E$ - extractable substances content, \%

$a$ - extract amount, $\mathrm{g}$

$n$ - mass of dried material, $\mathrm{g}$

To determine the cellulose content a $1 \mathrm{~g}$ of extracted fraction of the material was weighed with an accuracy of $0.001 \mathrm{~g}$. After that, the sample was mixed with ethyl alcohol and nitric acid in a ratio of $4: 1$. Counting the time from boiling, the contents were heated for one hour, then the liquid from the sediment was filtered through the Schott G3 filter. The residue in the flask was again flooded with a mixture of alcohol and acid and then incubated in a water bath and repeated 3 times. The filter was dried to constant weight at $105^{\circ} \mathrm{C}$ (Krutul, 2002). The final result was the arithmetic mean of obtained values.

The cellulose content was calculated in accordance to the formula:

$$
C=\frac{100 \cdot b}{a}
$$

where:

$C$ - cellulose content in the analysed sample, \%

$a$ - mass of dried material $\mathrm{g}$

$b$ - mass of obtained cellulose, $\mathrm{g}$

A $1 \mathrm{~g}$ of extracted biomass was weighed with an accuracy of $0.001 \mathrm{~g}$ to determine the holocellulose content. Then the sample was flooded with $45 \mathrm{~cm}^{3}$ of distilled water. Material was placed in the flask and was heated for 10 minutes in the bath at temperature of $75^{\circ} \mathrm{C}$. After that, the $0.5 \mathrm{~g}$ of sodium chlorite and 6 drops of acetic acid were added to the sample. Material was placed in a water bath for 60 min once again and from time to time was mixed. This action was repeated four times and then flasks were cooled in cold water for $10 \mathrm{~min}$. After cooling, the contents of flasks were filtered throw the Schott G2 filter and were washed with $500 \mathrm{ml}$ of distilled water. Filters were placed in the drier at the temperature of $105^{\circ} \mathrm{C}$ and were dried to a constant weight (Kačik and Solár, 1999). The final result was the arithmetic mean of obtained values.

The holocellulose content was calculated in accordance to the following formula: 


$$
\mathrm{H}=\frac{100 \cdot \mathrm{a}}{\mathrm{n}}
$$

where:

$\mathrm{H}-$ holocellulose content, $\%$

a - mass of sediment, $g$

$\mathrm{n}-$ mass of dried biomass, $\mathrm{g}$

A $1 \mathrm{~g}$ of extracted dried material was weighed with an accuracy of $0.001 \mathrm{~g}$ to determine the lignin content. Then it was flooded with $15 \mathrm{~cm}^{3}$ of $72 \%$ sulphuric acid. The mixture in the beaker was mixed, and the action was repeated every 10 minutes for $2 \mathrm{~h}$. After that to the mixture was added the $560 \mathrm{ml}$ of distilled water and it was placed in a water bath at a temperature of $95^{\circ} \mathrm{C}$. The content was heated for $4 \mathrm{~h}$ and then was filtered and washed with $500 \mathrm{ml}$ of hot distilled water to wash off the acid. After drying the obtained material was used to spectrophotometry test in order to determine the concentration of lignin at wavelength of $205 \mathrm{~nm}$.

Percentage analysis of the elements $\mathrm{C}, \mathrm{H}, \mathrm{N}, \mathrm{S}, \mathrm{O}$ in tested samples was performed using the "vario MACRO elementar" element analyser. As a catalyst for combustion, regardless of the tested material, a pure oxygen (99.995\%) was used. While to rinsing the device between the tests a helium of min. $99.996 \%$ purity was used. The biomass samples were dried to a dry state, finely precisely milled and sieved onto a sieve with $2 \mu \mathrm{m}$ of opening angle. To one repetition, a $50 \mathrm{mg}$ of material was used. To tested sample a $50 \mathrm{mg}$ of tungsten trioxide $\mathrm{WO}_{3}$ was added, which served as an additional catalyst. The sample for analysis was prepared in a zinc film, which was then pelletized using a press. The device was flushed from the residual gases and was calibrated using sulphanilamide. The measurement was done automatically.

The calorific values of biomass were determined according to PN-ISO 1928:2002 standard by determine a gross calorific values using KL-10 calorimeter. Tests were carried out for dried material, and gross calorific value was calculated using a following formula:

$$
Q_{i}=\left(Q_{s}-206 w(H)\right) \bullet(1-0,01 w)-23 w
$$

where:

$\mathrm{Q}_{\mathrm{i}}$ - gross calorific value, $\mathrm{J} \cdot \mathrm{g}^{-1}$,

$\mathrm{Q}_{\mathrm{s}}-$ net calorific value, $\mathrm{J} \cdot \mathrm{g}^{-1}$,

$\mathrm{w}(\mathrm{H})$ - hydrogen content in a dry fuel, $\%$,

$\mathrm{w}$ - total moisture content, \%,

All tests were performed in three repetitions. The statistical analysis of the results was conducted using a computer program Statistica v.12.

\section{RESULTS AND DISCUSSION}

Materials that contains compounds such as cellulose, hemicellulose and lignin belongs to easily biodegradable materials. Based on the conducted tests (Table 1) it can be stated that tested biomasses consist mainly of these compounds. During steam explosion process a significant loss of hemicellulose contents in samples can be observed. In addition, the share of extraction components increases. It is possible that part of the hemicellulose with degraded chains is dissolved and washed out by extraction.

Based on the tested samples, it can be concluded that the steam explosion process is relatively aggressive for tested biomass. As a result, over $24 \%$ of hemicellulose is lost or degraded, and the content of cellulose and lignin remains unchanged.

The biomass is heated up by the condensation of steam so its "capillary-like" microporous structure is soaked with liquid hot water (Chornet et al., 1991). This causes the release of acids from the hemicellulose fraction and decreasing the $\mathrm{pH}$ to 3-4 level (Mosier et al., 2005). The moderate acidic conditions can especially hydrolyse the hemicellulose (auto hydrolysis), but cleavage the lignin ether bonds is also included (Li et al., 2007).

Table 1. Organic compounds included in the tested material

\begin{tabular}{|c|c|c|c|c|c|}
\hline Name & Extraction ingredients, \% & Cellulose, $\%$ & Lignin, $\%$ & Holocellulose, $\%$ & Hemicellulose, $\%$ \\
\hline Raw material & $3.4 \pm 0.1$ & $52 \pm 1.9$ & $30.9 \pm 1.6$ & $76.8 \pm 1.3$ & $24.8 \pm 0.6$ \\
\hline Material after steam explosion & $12.8 \pm 0.2$ & $51.8 \pm 1.1$ & $30.5 \pm 2.7$ & $52.5 \pm 0.4$ & $0.7 \pm 0.1$ \\
\hline Black pellet & $12.1 \pm 0.2$ & $53.0 \pm 0.5$ & $31.6 \pm 0.4$ & $53.2 \pm 0.4$ & $0.2 \pm 0.1$ \\
\hline
\end{tabular}

Studies on the content of elements have shown that the steam explosion of biomass resulted in a slight increase in a carbon content in the biomass (approximately 3\%) and hydrogen reduction (approximately $0.3 \%$ ). The nitrogen content remained unchanged while the sulphur was reduced by approx. 20\%. According to the CEN/TS 14961-1 standard, wood chips and pellets can be classified to a top class S0.02 in terms of sulphur content, and to N0.3 class in terms of nitrogen content. 
Table 2. Values of elements, gross and net calorific values and moisture content of tested biomass

\begin{tabular}{|c|c|c|c|c|c|c|c|}
\hline Name & $\mathrm{N}, \%$ & $\mathrm{C}, \%$ & $\mathrm{~S}, \%$ & $\mathrm{H}, \%$ & $\begin{array}{c}\text { Gross } \\
\text { calorific } \\
\text { value, } \mathrm{kJ}^{\mathrm{kg}} \mathrm{kg}^{-1}\end{array}$ & $\begin{array}{c}\text { Net } \\
\text { calorific } \\
\text { value, } \\
\mathrm{kJ} \cdot \mathrm{kg}^{-1}\end{array}$ & $\begin{array}{c}\text { Moisture } \\
\text { content, } \\
\%\end{array}$ \\
\hline Raw material & $0.227 \pm 0.005$ & $48.079 \pm 0.123$ & $0.132 \pm 0.012$ & $5.491 \pm 0.047$ & $18697 \pm 19$ & $16353 \pm 86$ & 6.1 \\
\hline Material after steam explosion & $0.234 \pm 0.013$ & $50.759 \pm 0.027$ & $0.104 \pm 0.006$ & $5.227 \pm 0.005$ & $19307 \pm 123$ & $15852 \pm 104$ & 11.6 \\
\hline Black pellet & $0.200 \pm 0.012$ & $51.481 \pm 0.019$ & $0.093 \pm 0.001$ & $5.221 \pm 0.005$ & $19553 \pm 110$ & $17376 \pm 99$ & 5.3 \\
\hline
\end{tabular}

All of the tested materials meet CEN/TS 14961-1 standard in terms of the moisture contents. The tested raw wood chips had lower moisture content than after the steam explosion and should be classified to M10 and M15 classes, respectively. The black pellet in accordance to above standard was in the M10 moisture class.

A CEN/TS 14961-4 standard classifies wood chips in terms of calorific value for classes: A1 with a calorific value above $13 \mathrm{MJ} \cdot \mathrm{kg}^{-1}, \mathrm{~A} 2$ - over $11 \mathrm{MJ} \cdot \mathrm{kg}^{-1}$, and class B1 and B2 where calorific values have to be reported. It follows that both: the raw chips and chips after steam explosion in terms of calorific value belong to class A1. On the other hand, the black pellets due to the calorific value were also in the highest class A1 (designed for public sector) and I1 (for industrial use) according to CEN/TS 14961-2 standard.

\section{CONCLUSIONS}

It has been found that the process of steam explosion mainly affects the breakdown of hemicellulose compounds. A processed biomass still contain mainly cellulose and lignin compounds that are easily biodegradable. The process results in a slight increase in material moisture contents and a decrease in calorific values. Further processing of raw materials in the agglomeration process reverses these negative changes in their properties.

It should be noted that no negative environmental effects of the steam explosion have been demonstrated in the test, on the contrary, the reduction of the sulphur content was noticed.

The tested materials were characterized by very low sulphur and nitrogen contents, high calorific values and low moisture contents and were in the highest classes in accordance to CEN/TS 14961- 1, CEN/TS 14961-2 and CEN/TS 14961-4 standards.

\section{REFERENCES}

1. Adapa P., Tabil L., Schoenau G., Opoku A. 2010. Pelleting characteristics of selected biomass with and without steam explosion pretreatment. International Journal of Agricultural and Biological Engineering, Vol. 3(3), pp. 62-79.

2. Antczak, A., Radomski, A., Zawadzki, J. 2006. Benzene Substitution in Wood Analysis. Annals of Warsaw Agricultural University, Forestry and Wood Technology, Vol. 58, pp. 15-19.

3. Björklund P., Joronen T., Bolhàr-Nordenkampf M. 2016. Steam-exploded pellets for heat and power generation. VGB PowerTech, Vol. 4, pp. 52-56.

4. Chornet E, Overend RP. Phenomenological kinetics and reaction engineering aspects of steam/aqueous treatments. In: Focher B, Marzetti A, Crescenzi V, editors. Steam explosion techniques-fundamentals and industrial applications. Amsterdam: Gordon and Breach Science Publishers; 1991. p. 21-58.

5. CEN/TS 14961-1: E. Solid biofuels - Fuel specifications and classes — Part 1: General requirements.

6. CEN/TS 14961-2: E. Solid biofuels — Fuel specifications and classes — Part 2: Graded wood pellets

7. CEN/TS 14961-4: E. Solid biofuels — Fuel specifications and classes — Part 4: Graded wood chips.

8. Graham S., Ogunfayo I., Hall M. R., Snape C., Quick W., Weatherstone S., Eastwick C. 2016. Changes in mechanical properties of wood pellets during artificial degradation in laboratory environment. Fuel Processing Technology, Vol. 148, pp. 395-402. https://doi.org/10.1016/j.fuproc.2016.03.020

9. Grala A., Zieliński M., Dudek M., Dębowski M., Ostrowska K. 2014. Technologie kondycjonowania biomasy lignocelulozowej przed procesem fermentacji metanowej. Interdyscyplinarne Zagadnienia w Inżynierii i Ochronie Środowiska, 4 pp. 395-402

10. Holtzapple M. T., A. E. Humphrey, J. D. Taylor. 1989. Energy Requirements for the Size Reduction of Poplar and Aspen Wood. Biotechnology and Bioenginering, Vol. 33: pp. 207-210.https://doi.org/10.1002/bit.260330210

11. Jakubiak M., Kordylewski W. 2009. Toryfikacja biomasy. Politechnika Wrocławska, Instytut Techniki cieplnej i Mechaniki Płynów, pp. 1-9. [In Polish]

12. Krutul D. 2002. Ćwiczenia z chemii drewna oraz z wybranych zagadnień chemii organicznej. Wydawnictwo SGGW, Warszawa. [In Polish]

13. Kačik, F., Solár, R. 1999. Analiticka Chemia Dreva. Technicka Univerzita, Zvolene [In Polish]

14. Lam, P. S., S. Sokhansanj, X. Bi, C. J. Lim, L. J. Naimi, M. Hoque, S. Mani, A. R. Womac, S. Narayan, X. P. Ye. 2008. Bulk Density of wet and dry wheat straw and switchgrass particles. Applied Engineering in Agriculture, Vol. 24 (3), pp. 351-358. https://doi.org/10.13031/2013.24490

15. Li J, Henriksson G, Gellerstedt G. 2007. Lignin depolymerization/repolymerization and its critical role for delignification of aspen wood by steam explosion. Bioresource Technology, Vol 98, pp. 3061-3068. https://doi.org/10.1016/j.biortech.2006.10.018

16. Mani, S., Tabil, L.G., Sokhansanj, S. 2006. Effects of compressive force, particle size and moisture content on mechanical properties of biomass pellets from grasses. Biomass and Bioenergy, Vol. 30, pp. $648-654$. https://doi.org/10.1016/j.biombioe.2005.01.004

17. Mosier, N, Wyman, C, Dale, B, Elander, R, Lee, YY, Holtzapple, M, Ladisch, M. 2005. Features of promising technologies for pretreatment of lignocellulosic biomass. Bioresource Technology, Vol. 96, pp. $673-86$. https://doi.org/10.1016/j.biortech.2004.06.025 
18. PN-92/P-50092 Surowce dla przemysłu papierniczego. Drewno. Analiza chemiczna. [In Polish]

19. PN-ISO 1928:2002 Paliwa stałe - Oznaczenie ciepła spalania metoda spalania w bombie kalorymetrycznej i obliczenie wartości opałowej. [In Polish]

20. PN-EN 15414-3:2011. Stałe paliwa wtórne - Oznaczanie zawartości wilgoci metoda suszarkowa. Część 3: Wilgoć w ogólnej próbce analitycznej. [In Polish]

21. Stelte W. 2013. Steam explosion for biomass pre-treatment. Danish Technological Institute, Taastrup, DK, pp. 15 